Check for updates

Cite this: RSC Adv., 2017, 7, 33273

\title{
Symmetric sodium-ion batteries based on the phosphate material of NASICON-structured $\mathrm{Na}_{3} \mathrm{CO}_{0.5} \mathrm{Mn}_{0.5} \mathrm{Ti}\left(\mathrm{PO}_{4}\right)_{3} \dagger$
}

\author{
Hongbo Wang, ${ }^{a}$ Chao Chen, ${ }^{b}$ Chao Qian, ${ }^{\text {a }}$ Chengdu Liang ${ }^{a}$ and Zhan Lin (iD *ab
}

Symmetric sodium-ion batteries (NIBs) have become a research focus since they employ bi-functional electrode materials as both the cathode and the anode, resulting in reduced manufacturing cost and simplified fabrication process. Layered oxide bi-functional materials have received great attention recently, while phosphate analogues have rarely been involved in the same energy storage system. Herein, we report a new phosphate compound of $\mathrm{Na}_{3} \mathrm{Co}_{0.5} \mathrm{Mn}_{0.5} \mathrm{Ti}\left(\mathrm{PO}_{4}\right)_{3}$, and investigate the electrochemical performances of this bi-functional material in traditional organic electrolyte. The results demonstrate that $\mathrm{Na}_{3} \mathrm{CO}_{0.5} \mathrm{Mn}_{0.5} \mathrm{Ti}\left(\mathrm{PO}_{4}\right)_{3}$ can deliver compatible capacities of ca. $50 \mathrm{~mA} \mathrm{~h} \mathrm{~g}{ }^{-1}$ at a rate of $0.1 \mathrm{C}$ in both potential windows of 2.8-4.2 $\mathrm{V}$ and 1.6-2.8 V. Furthermore, when applied as anode material for rechargeable NIBs, $\mathrm{Na}_{3} \mathrm{CO}_{0.5} \mathrm{Mn}_{0.5} \mathrm{Ti}\left(\mathrm{PO}_{4}\right)_{3}$ can exhibit an impressive cycling stability with capacity retention of $94 \%$ exceeding 550 cycles at a rate of $0.2 \mathrm{C}$. In addition, deriving from $\mathrm{Na}_{3} \mathrm{CO}_{0.5} \mathrm{Mn}_{0.5} \mathrm{Ti}_{(}\left(\mathrm{PO}_{4}\right)_{3}$ as simple active material, we construct a symmetric NIB with an average

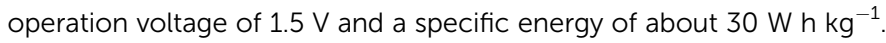

Received 9th May 2017

Accepted 25th June 2017

DOI: 10.1039/c7ra05214f

rsc.li/rsc-advances the positive and negative electrodes. ${ }^{14}$ In light of redox couples of different transition metals (TMs) in layered oxides (O3-type or P2-type), full symmetric NIBs with the same active material in both the cathode and anode have been proposed recently. ${ }^{15,16} \mathrm{In}$ parallel, a suite of sodium polyanionic compounds have rarely been unveiled as bi-functional electrode materials showing commendable electrochemical properties. ${ }^{17}$

Polyanions provide potential advantages such as good structural and thermal stability, flat voltage response on sodium-ion (de)intercalation, and better capacity retention endowed by their structural energetics and robust frameworks. ${ }^{18,19}$ Among different polyanionic frameworks, phosphate-based systems are arguably the best in terms of thermal and chemical stability. Importantly, the widely available commercialized material in LIBs, lithium iron phosphate, sheds light on us to develop safe phosphate analogues in NIBs. In addition, phosphate-based sodium compounds have the advantage of lacking significant sensitivity to ambient atmosphere, i.e., $\mathrm{H}_{2} \mathrm{O}$ and $\mathrm{CO}_{2}$, which enabled them as a more promising candidate for commercialization when comparing to sodium layered metal oxides. ${ }^{20,21}$

Herein, we reported the electrochemical performance of a new phosphate-based compound $\mathrm{Na}_{3} \mathrm{Co}_{0.5} \mathrm{Mn}_{0.5} \mathrm{Ti}\left(\mathrm{PO}_{4}\right)_{3}$ as the bi-functional electrode material for room-temperature NIBs. It is demonstrated that $\mathrm{Na}_{3} \mathrm{Co}_{0.5} \mathrm{Mn}_{0.5} \mathrm{Ti}\left(\mathrm{PO}_{4}\right)_{3}$ exhibited two couples of redox centers at about $3.55 \mathrm{~V}$ and $4.10 \mathrm{~V}$ in the potential range of $2.8-4.2 \mathrm{~V}$, and a couple of redox center at $c a$. $2.20 \mathrm{~V}$ in the potential range of 1.6-2.8 $\mathrm{V}$. The utilization of
${ }^{a}$ Key Laboratory of Biomass Chemical Engineering of Ministry of Education, College of Chemical and Biological Engineering, Zhejiang University, Hangzhou 310027, P. R. China.E-mail: qianchao@zju.edu.cn; zhanlin@zju.edu.cn

${ }^{b}$ College of Light Industry and Chemical Engineering, Guangdong University of Technology, Guangzhou 510006, P. R. China

$\dagger$ Electronic supplementary information (ESI) available. See DOI: 10.1039/c7ra05214f 
$\mathrm{Na}_{3} \mathrm{Co}_{0.5} \mathrm{Mn}_{0.5} \mathrm{Ti}\left(\mathrm{PO}_{4}\right)_{3}$ as the active material, we fabricated a symmetric NIB with an average output voltage of $1.5 \mathrm{~V}$ and an

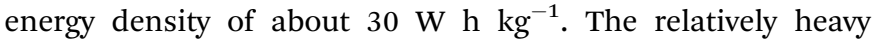
framework of typical NASICON compound lowers its gravimetric energy density. However, there has been a huge demand for stationary batteries, where the energy density or specific energy is not the priority, ${ }^{22,23}$ and thus $\mathrm{Na}_{3} \mathrm{Co}_{0.5} \mathrm{Mn}_{0.5} \mathrm{Ti}\left(\mathrm{PO}_{4}\right)_{3}$ can be considered as a promising electrode material for potentially application in the massive stationary energy storage system.

The crystal structure of $\mathrm{Na}_{3} \mathrm{Co}_{0.5} \mathrm{Mn}_{0.5} \mathrm{Ti}\left(\mathrm{PO}_{4}\right)_{3}$ synthesized by the sol-gel method was examined by powder X-ray diffraction (XRD) and the pattern is shown in Fig. 1. All diffraction lines of the XRD pattern can be indexed as a rhombohedral phase with a space group of $R \overline{3} C$. No impure crystalline phase was found in the pattern and the crystal structure was refined by the Rietveld method with the software of GSAS. The refinement result is shown in the ESI, Table S1, $\dagger$ indicating that the as-synthesized $\mathrm{Na}_{3} \mathrm{Co}_{0.5} \mathrm{Mn}_{0.5} \mathrm{Ti}\left(\mathrm{PO}_{4}\right)_{3}$ material is a typical NASICON-structured compound, and the schematical unit cell is represented in the inset of Fig. 1. In $\mathrm{Na}_{3} \mathrm{Co}_{0.5} \mathrm{Mn}_{0.5} \mathrm{Ti}\left(\mathrm{PO}_{4}\right)_{3}, \mathrm{TMO}_{6}(\mathrm{TM}=\mathrm{Co}, \mathrm{Mn}$, Ti) octahedra and $\mathrm{PO}_{4}$ tetrahedra share one corner to form a three-dimensional (3D) framework. Two independent types of sodium-ions are located in interstitial sites of the framework with different oxygen environments: a single interstitial site per unit cell with six-fold coordination (Na1 site) is occupied by a less mobile sodium-ion, while three equivalent sites per unit cell with eight-fold coordination ( $\mathrm{Na} 2$ sites) are occupied by two mobile sodium-ions. Sodium-ions positioned at $\mathrm{Na} 2$ sites can be (de)intercalation for electrochemical activity. ${ }^{\mathbf{2 4 , 2 5}}$ Therefore, the de-intercalation of one sodium-ion per unit cell from $\mathrm{Na}_{3}$ $\mathrm{Co}_{0.5} \mathrm{Mn}_{0.5} \mathrm{Ti}\left(\mathrm{PO}_{4}\right)_{3}$ with the formation of $\mathrm{Na}_{2} \mathrm{Co}_{0.5} \mathrm{Mn}_{0.5} \mathrm{Ti}\left(\mathrm{PO}_{4}\right)_{3}$ through the $\mathrm{TM}^{3+} / \mathrm{TM}^{2+}(\mathrm{TM}=\mathrm{Co}, \mathrm{Mn})$ redox couple, while the intercalation of another sodium-ion per unit cell into $\mathrm{Na}_{3}$ $\mathrm{Co}_{0.5} \mathrm{Mn}_{0.5} \mathrm{Ti}\left(\mathrm{PO}_{4}\right)_{3}$ with the formation of $\mathrm{Na}_{4} \mathrm{Co}_{0.5} \mathrm{Mn}_{0.5} \mathrm{Ti}\left(\mathrm{PO}_{4}\right)_{3}$ through the $\mathrm{Ti}^{4+} / \mathrm{Ti}^{3+}$ redox couple.

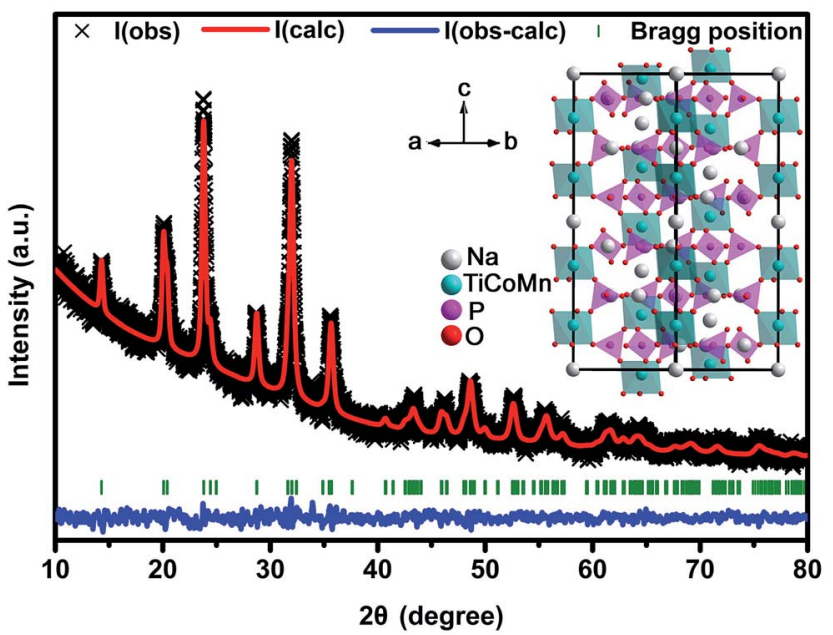

Fig. 1 XRD pattern of $\mathrm{Na}_{3} \mathrm{CO}_{0.5} \mathrm{Mn}_{0.5} \mathrm{Ti}_{(}\left(\mathrm{PO}_{4}\right)_{3}$ and Rietveld refinement Inset schematically shows the crystal structure of $\mathrm{Na}_{3} \mathrm{CO}_{0.5} \mathrm{Mn}_{0.5} \mathrm{Ti}\left(\mathrm{PO}_{4}\right)_{3}$.
The morphology of $\mathrm{Na}_{3} \mathrm{Co}_{0.5} \mathrm{Mn}_{0.5} \mathrm{Ti}\left(\mathrm{PO}_{4}\right)_{3}$ was investigated by scanning electron microscopy (SEM) and transmission electron microscopy (TEM). As shown in Fig. $2 \mathrm{a}, \mathrm{Na}_{3} \mathrm{Co}_{0.5} \mathrm{Mn}_{0.5^{-}}$ $\mathrm{Ti}\left(\mathrm{PO}_{4}\right)_{3}$ powder is irregular secondary particles and typically a few micrometers in size. High-magnification SEM image reveals that the worm-like microparticles consist of nanoparticles with interparticle pores (Fig. 2b). TEM image confirms that the $\mathrm{Na}_{3} \mathrm{Co}_{0.5} \mathrm{Mn}_{0.5} \mathrm{Ti}\left(\mathrm{PO}_{4}\right)_{3}$ microparticles are composed of nanosized primary particles well dispersed in carbon matrix (Fig. 2c). As shown in Fig. 2d, the presence of carbon was also confirmed by Raman spectrum, and the amount of carbon in the $\mathrm{Na}_{3} \mathrm{Co}_{0.5} \mathrm{Mn}_{0.5} \mathrm{Ti}\left(\mathrm{PO}_{4}\right)_{3}$ powder was determined to be $c a .7 .6$ $\mathrm{wt} \%$ by thermogravimetric analysis (TGA, Fig. 2e). Energy dispersive X-ray spectroscopy (EDS) test was carried out by pressing the $\mathrm{Na}_{3} \mathrm{Co}_{0.5} \mathrm{Mn}_{0.5} \mathrm{Ti}\left(\mathrm{PO}_{4}\right)_{3}$ powder into a pellet, and the elements of $\mathrm{Na}, \mathrm{Co}, \mathrm{Mn}, \mathrm{Ti}, \mathrm{P}, \mathrm{O}$, and $\mathrm{C}$ were found as shown in Fig. 2f. Furthermore, the chemical composition of the prepared sample was determined by inductively coupled plasma-optical emission spectroscopy (ICP-OES), and element analysis yielded the $\mathrm{Na}: \mathrm{Co}: \mathrm{Mn}: \mathrm{Ti}: \mathrm{P}$ mole ratio of $2.92: 0.49: 0.47: 1.02: 3$, which is consistent with the $\mathrm{Na}_{3}$ $\mathrm{Co}_{0.5} \mathrm{Mn}_{0.5} \mathrm{Ti}\left(\mathrm{PO}_{4}\right)_{3}$ lattice within the error of the determination.

The electrochemical performances of the $\mathrm{Na}_{3} \mathrm{Co}_{0.5} \mathrm{Mn}_{0.5^{-}}$ $\mathrm{Ti}\left(\mathrm{PO}_{4}\right)_{3}$ electrode as cathode were first investigated by cyclic voltammetry $(\mathrm{CV})$ test in a half-cell system for NIBs. As shown in Fig. 3a, the CV data evidenced two distinct redox peaks positioned at $3.55 \mathrm{~V}$ and $4.10 \mathrm{~V}$. Based on the supplementary analysis (see ESI, Fig. S1†) and the redox potentials of TMs in the NASICON-related cathode materials, ${ }^{26,27}$ these two pair of peaks correspond to the redox centers of $\mathrm{Mn}^{3+} / \mathrm{Mn}^{2+}$ and $\mathrm{Co}^{3+} / \mathrm{Co}^{2+}$, respectively. Galvanostatic charge/discharge protocols were then used to measure electrochemical sodium (de)intercalation from $\mathrm{Na}_{3} \mathrm{Co}_{0.5} \mathrm{Mn}_{0.5} \mathrm{Ti}\left(\mathrm{PO}_{4}\right)_{3}$ as shown in Fig. 3b. In the light of the expected redox of one electron for $\mathrm{TM}^{3+} / \mathrm{TM}^{2+}(\mathrm{TM}=\mathrm{Co}$, $\mathrm{Mn}$ ), a theoretical capacity of $58 \mathrm{~mA} \mathrm{~h} \mathrm{~g}^{-1}$ is expected. However, the profile exhibits a steady slope which most likely represents predominantly electrolyte decomposition catalyzed by the cathode and the first electrochemical charge capacity reaches 81 $\mathrm{mA} \mathrm{h} \mathrm{g}^{-1}$ at the $0.1 \mathrm{C}$ rate, while the discharge capacity is $c a .50$ $\mathrm{mA} \mathrm{h} \mathrm{g}^{-1}$, corresponding to a relatively low coulombic efficiency

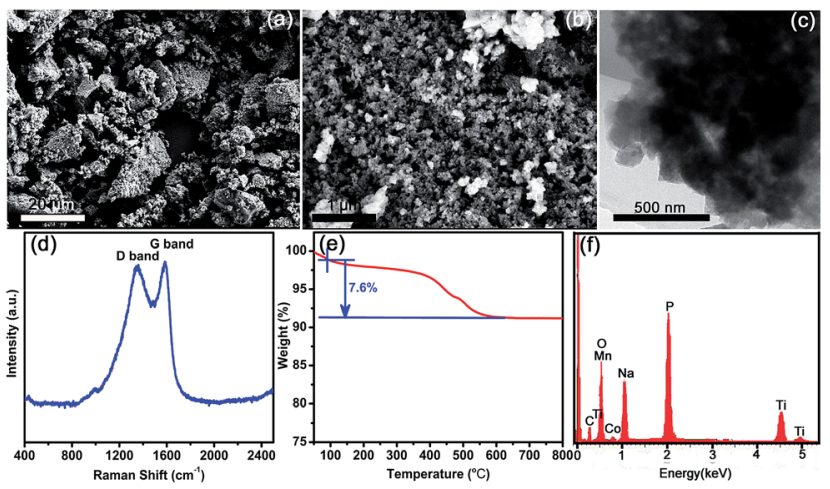

Fig. 2 Characterizations of the $\mathrm{Na}_{3} \mathrm{CO}_{0.5} \mathrm{Mn}_{0.5} \mathrm{Ti}\left(\mathrm{PO}_{4}\right)_{3}$ material. (a-c) SEM, HRSEM, and TEM images. (d-f) Raman spectrum, TGA, and EDS analysis. 

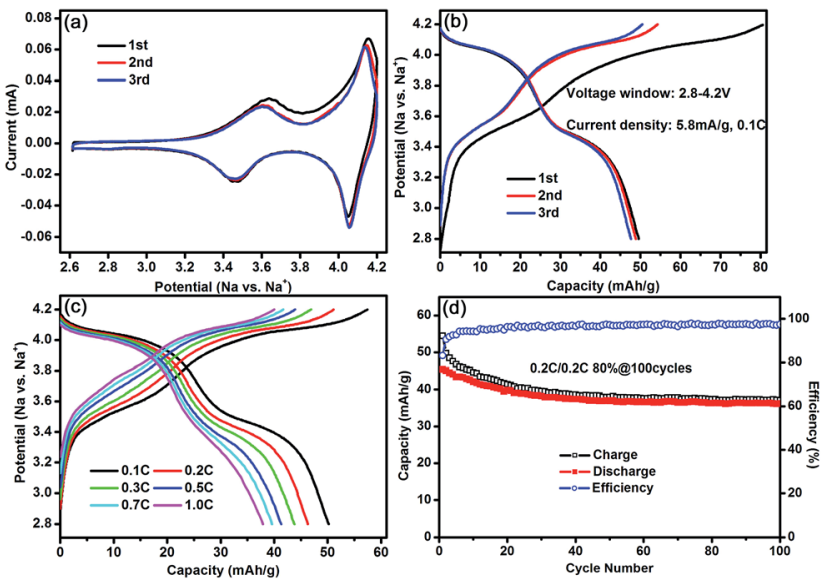

Fig. 3 Electrochemical performance of $\mathrm{Na}_{3} \mathrm{CO}_{0}{ }_{5} \mathrm{Mn}_{0}{ }_{5} \mathrm{Ti}\left(\mathrm{PO}_{4}\right)_{3}$ electrode as cathode in half-cell system. (a) Cyclic voltammograms measured between $2.6 \mathrm{~V}$ and $4.2 \mathrm{~V}$ at a scan rate of $0.05 \mathrm{mV} \mathrm{s}^{-1}$. (b) Typical charge/discharge profiles in the voltage of $2.8-4.2 \mathrm{~V}$ at a rate of $0.1 \mathrm{C}$. (c) Rate capabilities at different rates from $0.1 \mathrm{C}$ to $1 \mathrm{C}$. (d) Corresponding cycling performance with coulombic efficiency over 100 cycles at a rate of $0.2 C$.

of $\sim 62 \%$. After initial three cycles of $0.1 \mathrm{C}$, the cells were then tested with charge/discharge cycles such as various rate performances from 0.1 to $1 \mathrm{C}$ and galvanostatic cycling at a rate of $0.2 \mathrm{C}$. As shown in Fig. 3c, in accordance with the CV data, the charge/ discharge curves, obtained even at the $1 \mathrm{C}$ rate, are characterized by two plateaus, i.e., the one at about $4.0 \mathrm{~V}$ and the other at about $3.4 \mathrm{~V}$, delivering a reversible capacity of $\sim 38 \mathrm{~mA} \mathrm{~h} \mathrm{~g}{ }^{-1}$. Furthermore, all the XRD peaks of $\mathrm{Na}_{3} \mathrm{Co}_{0.5} \mathrm{Mn}_{0.5} \mathrm{Ti}\left(\mathrm{PO}_{4}\right)_{3}$ shifted to higher angles when charging to $4.2 \mathrm{~V}$, indicating a volume shrinkage owing to the extraction of sodium-ions from the NASICON structure $;^{28}$ and the diffraction peaks of the electrode recovered to its original state on discharging to $2.8 \mathrm{~V}$ (see ESI, Fig. S2 $\uparrow$ ), which indicates the reversibility of structure change of the $\mathrm{Na}_{3} \mathrm{Co}_{0.5} \mathrm{Mn}_{0.5} \mathrm{Ti}\left(\mathrm{PO}_{4}\right)_{3}$ electrode during charge/discharge. However, the cycling stability of the $\mathrm{Na}_{3} \mathrm{Co}_{0.5} \mathrm{Mn}_{0.5} \mathrm{Ti}\left(\mathrm{PO}_{4}\right)_{3}$ electrode in Fig. 3d are not encouraging and the coulombic efficiency is only about $97 \%$ in the successive cycles. As mentioned above, the oxidation of electrolyte at the cathode surface is probable at high voltages. ${ }^{29,30}$

The electrochemical properties of the $\mathrm{Na}_{3} \mathrm{Co}_{0.5} \mathrm{Mn}_{0.5} \mathrm{Ti}\left(\mathrm{PO}_{4}\right)_{3}$ electrode as anode were also evaluated in a half-cell system for NIBs. As shown in Fig. 4a, a pair of very symmetric redox peaks appeared at $2.05 \mathrm{~V}$ and $2.37 \mathrm{~V}$, which is ascribed to the $\mathrm{Ti}^{4+} / \mathrm{Ti}^{3+}$ redox couple in $\mathrm{Na}_{3} \mathrm{Co}_{0.5} \mathrm{Mn}_{0.5} \mathrm{Ti}\left(\mathrm{PO}_{4}\right)_{3}$ lattice (see ESI, Fig. S3 $\dagger$ ), in agreement with the $\mathrm{Ti}^{4+} / \mathrm{Ti}^{3+}$ redox couple in $\mathrm{NaTi}_{2}\left(\mathrm{PO}_{4}\right)_{3}{ }^{31,32}$ In addition, the peak shape and peak position remained unchanged during the successive scans, indicating excellent reversible intercalation/deintercalation reaction of sodium-ions into/out of the $\mathrm{Na}_{3} \mathrm{Co}_{0.5} \mathrm{Mn}_{0.5} \mathrm{Ti}\left(\mathrm{PO}_{4}\right)_{3}$ lattice. The discharge and charge capacity of the first cycle was about 56 and $52 \mathrm{~mA} \mathrm{~h} \mathrm{~g}^{-1}$, respectively. Almost all of the inserted sodium-ions can be extracted from the interstitial site of $\mathrm{TMO}_{6}$ octahedra, and the initial coulombic efficiency was $\sim 93 \%$. After the first cycle, the reversible capacity remained stable at $\sim 52 \mathrm{~mA} \mathrm{~h} \mathrm{~g}{ }^{-1}$ and the
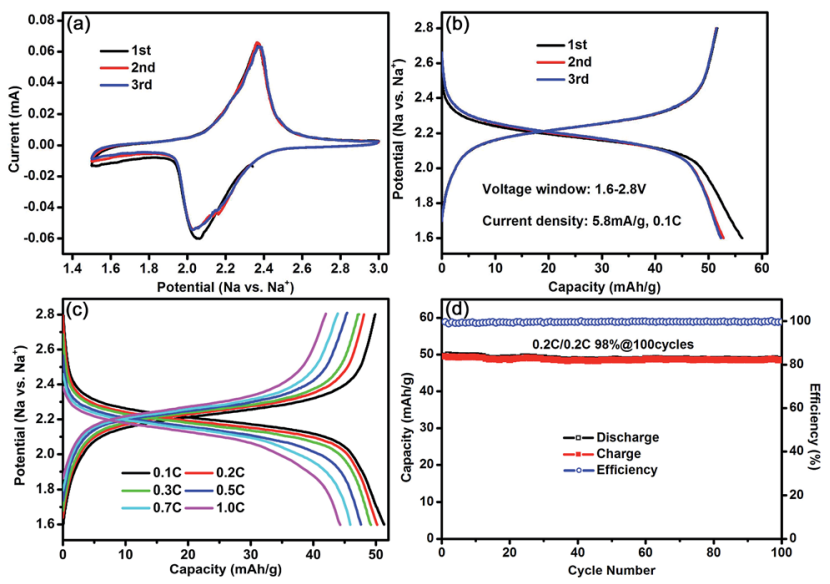

Fig. 4 Electrochemical performance of $\mathrm{Na}_{3} \mathrm{Co}_{0.5} \mathrm{Mn}_{0.5} \mathrm{Ti}\left(\mathrm{PO}_{4}\right)_{3}$ electrode as anode in half-cell system. (a) Cyclic voltammograms between $1.5 \mathrm{~V}$ and $3.0 \mathrm{~V}$ at a scan rate of $0.05 \mathrm{mV} \mathrm{s}^{-1}$. (b) Typical discharge/ charge profiles in the voltage of $1.6-2.8 \mathrm{~V}$ at a rate of $0.1 \mathrm{C}$. (c) Rate capabilities at different rates from 0.1 to $1 \mathrm{C}$. (d) Corresponding cycling performance with coulombic efficiency over 100 cycles at a rate of $0.2 \mathrm{C}$.

coulombic efficiency kept at $\sim 100 \%$ (Fig. $4 \mathrm{~b}$ ). The rate performance of the $\mathrm{Na}_{3} \mathrm{Co}_{0.5} \mathrm{Mn}_{0.5} \mathrm{Ti}\left(\mathrm{PO}_{4}\right)_{3}$ anode was also evaluated at various rates from $0.1 \mathrm{C}$ to $1 \mathrm{C}$ after the initial three cycles. The reversible capacities are $51,48,47,46,44$, and $42 \mathrm{~mA} \mathrm{~h} \mathrm{~g}^{-1}$ at an increasing current rate of $0.1,0.2,0.3,0.5,0.7$, and $1 \mathrm{C}$, respectively, indicating a relatively good rate capability (Fig. 4c). The $\mathrm{Na}_{3} \mathrm{Co}_{0.5} \mathrm{Mn}_{0.5} \mathrm{Ti}\left(\mathrm{PO}_{4}\right)_{3}$ electrode was well cycled at $0.2 \mathrm{C}$ with a negligible capacity decay up to 100 cycles (Fig. 4d). Indeed, galvanostatic cycling still goes on and the $\mathrm{Na}_{3} \mathrm{Co}_{0.5} \mathrm{Mn}_{0.5} \mathrm{Ti}\left(\mathrm{PO}_{4}\right)_{3}$ anode constantly exhibited an excellent cyclability with capacity retention of $94 \%$ exceeding 550 cycles (see ESI, Fig. S4†), which is due to stable 3D framework of the NASICON structure that facilitates reversible intercalation/de-intercalation of sodium-ions without structural change for the $\mathrm{Na}_{3} \mathrm{Co}_{0.5} \mathrm{Mn}_{0.5} \mathrm{Ti}\left(\mathrm{PO}_{4}\right)_{3}$ anode (see ESI, Fig. S5 $\dagger$ ). Therefore, although $\mathrm{Na}_{3} \mathrm{Co}_{0.5} \mathrm{Mn}_{0.5} \mathrm{Ti}\left(\mathrm{PO}_{4}\right)_{3}$ offers a higher redox potential compared to the equivalent transition metal oxide owing to the inductive effect of the polyanions, whose strong covalent framework induces electron density away from the metal center, it presents good structural and thermal stability, a flatter voltage response upon sodium (de)intercalation and better capacity retention endowed by their robust frameworks. ${ }^{33}$ In these aspects, $\mathrm{Na}_{3} \mathrm{Co}_{0.5} \mathrm{Mn}_{0.5} \mathrm{Ti}\left(\mathrm{PO}_{4}\right)_{3}$ is a predominately promising anode material for high-performance NIBs.

In order to reduce the irreversibility effect of the $\mathrm{Na}_{3} \mathrm{Co}_{0.5^{-}}$ $\mathrm{Mn}_{0.5} \mathrm{Ti}\left(\mathrm{PO}_{4}\right)_{3}$ material, mainly in the cathode side in the first cycle, cycled $\mathrm{Na}_{3} \mathrm{Co}_{0.5} \mathrm{Mn}_{0.5} \mathrm{Ti}\left(\mathrm{PO}_{4}\right)_{3}$ electrodes in the half-cells are used as both the positive and negative electrode in sodium-ion full-cells. In the cathode-limited cell, as shown in Fig. $5 \mathrm{a}$, the capacity was normalized to $1.0 \mathrm{~mA}$ h for the anode charge and the capacity of the cathode relative to that of anode was reduced. Based on the mass of cathode, a reversible discharge capacity of $43 \mathrm{~mA} \mathrm{~h} \mathrm{~g}^{-1}$ was obtained at a rate of $0.1 \mathrm{C}$ in the first three cycles as shown in Fig. 5b. Rate capability was also evaluated with different charge/discharge rates from 0.1 to 

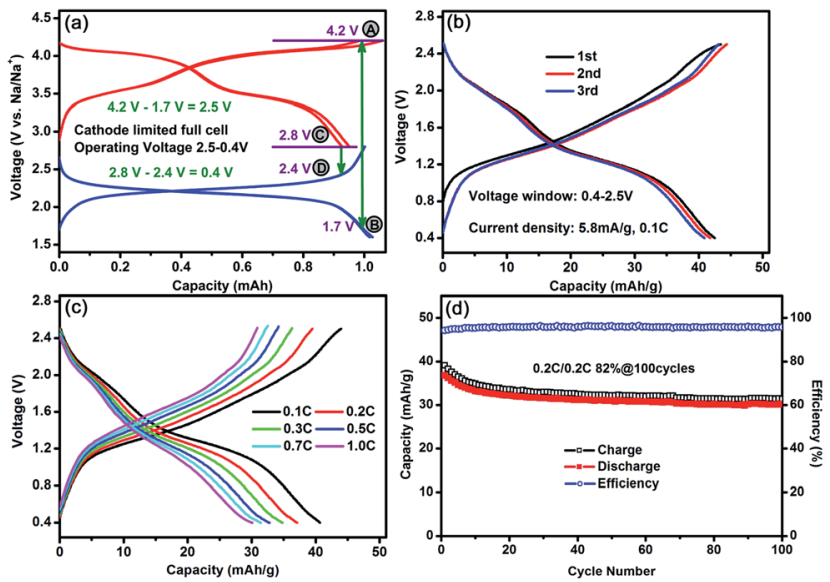

Fig. 5 Electrochemical performance of symmetric NIB with $\mathrm{Na}_{3}-$ $\mathrm{CO}_{0.5} \mathrm{Mn}_{0.5} \mathrm{Ti}\left(\mathrm{PO}_{4}\right)_{3}$ as both the cathode and the anode in full-cell system. (a) Detail of capacity matchup in the cathode-limited full-cell. (b) Typical charge/discharge profiles in the voltage of $0.4-2.5 \mathrm{~V}$ at a rate of $0.1 \mathrm{C}$. (c) Rate capabilities at different rates from 0.1 to $1 \mathrm{C}$. (d) Corresponding cycling performance with coulombic efficiency over 100 cycles at a rate of $0.2 \mathrm{C}$.

1C. As shown in Fig. 5c, the reversible capacity reaches to 33 $\mathrm{mA} \mathrm{h} \mathrm{g}^{-1}$ at a rate of $0.5 \mathrm{C}$, and even at the rate of $1 \mathrm{C}$, the discharge capacity remains at $30 \mathrm{~mA} \mathrm{~h} \mathrm{~g}^{-1}$, approximately $81 \%$ of the reversible capacity at $0.2 \mathrm{C}$. With a rate of $0.2 \mathrm{C}$, this symmetric full-cell offers $82 \%$ of capacity retention after 100 cycles (Fig. 5d). It is worthy to note that, at the upper limited voltage of $2.5 \mathrm{~V}$, for the cathode-limited full-cell, the potential of the cathode remains at $4.2 \mathrm{~V} v s . \mathrm{Na} / \mathrm{Na}^{+}$(point A in Fig. 5a), while that of the anode drops to $1.7 \mathrm{~V}$ (point B in Fig. 5a); and at the lower limited voltage of $0.4 \mathrm{~V}$, the potential of the cathode drops to $2.8 \mathrm{~V}$ (point $\mathrm{C}$ in Fig. 5a), while that of the anode is still at $2.4 \mathrm{~V}$ (point $\mathrm{D}$ in Fig. 5a). Therefore, compared with anode-limited full-cell, the cathode-limited symmetric NIB of $\mathrm{Na}_{3} \mathrm{Co}_{0.5} \mathrm{Mn}_{0.5} \mathrm{Ti}\left(\mathrm{PO}_{4}\right)_{3}$ exhibited higher average discharge voltage in behavior of two distinct voltage plateaux at $1.8 \mathrm{~V}$ and 1.2 $\mathrm{V}$ as shown in Fig. 5b, and hence higher energy density of $c a$. $30 \mathrm{~W} \mathrm{~h} \mathrm{~kg}{ }^{-1}$ was obtained based on the total mass of the cathode and the anode. However, the cycling stability was thus decreased because the oxidative decomposition of the electrolyte on the cathode surface is quite prominent at high voltage of $4.2 \mathrm{~V}$ in the cathode-limited cell, showing low coulombic efficiency of $\sim 96 \%$ in Fig. $5 \mathrm{~d}$. Therefore, it can be provided an excellent balance between energy density and cycling stability in optimizing the weight ratio of the cathode to that of the anode for this bi-functional electrode material of $\mathrm{Na}_{3} \mathrm{Co}_{0.5} \mathrm{Mn}_{0.5^{-}}$ $\mathrm{Ti}\left(\mathrm{PO}_{4}\right)_{3}$ in symmetric NIBs.

In summary, a new phosphate-based compound of $\mathrm{Na}_{3} \mathrm{Co}_{0.5} \mathrm{Mn}_{0.5} \mathrm{Ti}\left(\mathrm{PO}_{4}\right)_{3}$ was prepared by a facile sol-gel method, and was investigated as a positive and a negative electrode material for rechargeable NIBs. Both electrodes can be reversibly cycled in potential windows of $2.8-4.2 \mathrm{~V}$ and $1.6-2.8 \mathrm{~V}$, and the negative electrode exhibits an impressive cycling stability with capacity retention of $94 \%$ exceeding 550 cycles at a rate of $0.2 \mathrm{C}$. The use of $\mathrm{Na}_{3} \mathrm{Co}_{0.5} \mathrm{Mn}_{0.5} \mathrm{Ti}\left(\mathrm{PO}_{4}\right)_{3}$ as single active material, we constructed a symmetric NIB with an average operation voltage of $1.5 \mathrm{~V}$ and a specific energy of about $30 \mathrm{~W} \mathrm{~h} \mathrm{~kg}$. Although the heavy framework of NASICON compound decreased the gravimetric energy density of the full-cell, $\mathrm{Na}_{3} \mathrm{Co}_{0.5} \mathrm{Mn}_{0.5} \mathrm{Ti}\left(\mathrm{PO}_{4}\right)_{3}$ can be considered as a promising electrode material for potentially application in the large-scale stationary batteries.

\section{Experimental section}

\section{Material syntheses}

$\mathrm{Na}_{3} \mathrm{Co}_{0.5} \mathrm{Mn}_{0.5} \mathrm{Ti}\left(\mathrm{PO}_{4}\right)_{3}$ was fabricated via a facile sol-gel route. Initially, $\mathrm{CH}_{3} \mathrm{COONa}, \quad\left(\mathrm{CH}_{3} \mathrm{COO}\right)_{2} \mathrm{Co} \cdot 4 \mathrm{H}_{2} \mathrm{O}, \quad\left(\mathrm{CH}_{3} \mathrm{COO}\right)_{2}-$ $\mathrm{Mn} \cdot 4 \mathrm{H}_{2} \mathrm{O}, \mathrm{NH}_{4} \mathrm{H}_{2} \mathrm{PO}_{4}$, and citric acid with stoichiometric ratio were dissolved in distilled water with magnetic stirring. After adjusting the $\mathrm{pH}$ value to $\sim 4.0$ by using acetic acid, a diluted solution of tetrabutoxytitanium in ethanol was poured into the above solution to reach the final stoichiometry under continuous stirring. The obtained mixture was evaporated at $80^{\circ} \mathrm{C}$ in a water bath and further dried at $120{ }^{\circ} \mathrm{C}$ in an oven. The asprepared precursor was sintered at $350{ }^{\circ} \mathrm{C}$ under argon atmosphere for $3 \mathrm{~h}$, followed by $600{ }^{\circ} \mathrm{C}$ for $12 \mathrm{~h}$. The resulting material was grounded and sieved by 300 -mesh for electrochemical and structural studies.

\section{Material characterizations}

The structure of the $\mathrm{Na}_{3} \mathrm{Co}_{0.5} \mathrm{Mn}_{0.5} \mathrm{Ti}\left(\mathrm{PO}_{4}\right)_{3}$ material was characterized by using X-ray powder diffraction (XRD, Empyrean200895, PANalytical B.V., Netherlands) with $\mathrm{Cu} \mathrm{K} \alpha$ radiation. The XRD data was refined using GSAS Rietveld software and the electrodes obtained by dissembling batteries cycled at various voltages were characterized using ex situ XRD. The morphology of the sample was investigated by scanning electron microscopy (SEM, Ultra55, ZEISS, Germany) and transmission electron microscopy (TEM, JEM2100, JEOL, Japan) equipped with energy dispersive X-ray spectroscopy (EDS) for elemental analysis. Chemical composition of the sample was determined by inductively coupled plasma-optical emission spectroscopy (ICP-OES, Optima5300DV, PerkinElmer, USA). Xray photoelectron spectroscopy (XPS) measurements were performed on a ThermoFisher Escalab250Xi equipment. Raman spectra were acquired on confocal Horiba LabRAM HR microscope using $532 \mathrm{~nm}$ excitation. Thermal gravimetric analysis (TGA) was measured by a Mettler TA Q500 analyzer.

\section{Electrochemical measurements}

All the electrochemical tests were conducted using 2025-type coin cells. The working electrode was prepared by spreading the mixed slurry of active material and polyvinylidene fluoride (PVDF) binder in $N$-methyl-2-pyrrolidone (NMP) at a weight ratio of $9: 1$ onto $\mathrm{Al}$ foil, followed by drying at $120{ }^{\circ} \mathrm{C}$ under vacuum overnight. For half-cell tests, sodium metal was used as the counter and the reference electrode. In the symmetric sodium-ion full-cell, $\mathrm{Na}_{3} \mathrm{Co}_{0.5} \mathrm{Mn}_{0.5} \mathrm{Ti}\left(\mathrm{PO}_{4}\right)_{3}$ was used as both the positive and the negative electrode. The electrolyte was 1.0 $\mathrm{M} \mathrm{NaClO}_{4}$ dissolved in ethylene carbonate (EC), propylene 
carbonate (PC), and diethyl carbonate (DEC) at a volume ratio of $5: 3: 2$ with 5 vol\% of fluoroethylene carbonate (FEC) as electrolyte additive. Glass fiber was used as separator. Cyclic voltammetry (CV) measurements were performed on a CHI 760D electrochemistry workstation (Beijing, China) at a scan rate of $0.05 \mathrm{mV} \mathrm{s}^{-1}$. Galvanostatic charge and discharge tests were conducted on a LAND battery system (Wuhan, China) at room temperature.

\section{Acknowledgements}

This work was financially supported by Chinese government under the "Thousand Youth Talents Program", Zhejiang Province Science Fund for Distinguished Young Scholars (Project LR16B060001), and Key Technology and Supporting Platform of Genetic Engineering of Materials under State's Key Project of Research and Development Plan (Project 2016YFB0700600).

\section{References}

1 S.-W. Kim, D.-H. Seo, X. Ma, G. Ceder and K. Kang, Adv. Energy Mater., 2012, 2, 710-721.

2 D. Larcher and J.-M. Tarascon, Nat. Chem., 2015, 7, 19-29.

3 B. L. Ellis and L. F. Nazar, Curr. Opin. Solid State Mater. Sci., 2012, 16, 168-177.

4 M. D. Slater, D. Kim, E. Lee and C. S. Johnson, Adv. Funct. Mater., 2013, 23, 947-958.

5 H. Kang, Y. Liu, K. Cao, Y. Zhao, L. Jiao, Y. Wang and H. Yuan, J. Mater. Chem. A, 2015, 3, 17899-17913.

6 C. Fang, Y. Huang, W. Zhang, J. Han, Z. Deng, Y. Cao and H. Yang, Adv. Energy Mater., 2016, 6, 1501727.

7 Y. Li, S. Xu, X. Wu, J. Yu, Y. Wang, Y.-S. Hu, H. Li, L. Chen and X. Huang, J. Mater. Chem. A, 2015, 3, 71-77.

8 J. Qian, M. Zhou, Y. Cao, X. Ai and H. Yang, Adv. Energy Mater., 2012, 2, 410-414.

9 S.-M. Oh, S.-T. Myung, C. S. Yoon, J. Lu, J. Hassoun, B. Scrosati, K. Amine and Y.-K. Sun, Nano Lett., 2014, 14, 1620-1626.

10 H. Wang, Y. Xiao, C. Sun, C. Lai and X. Ai, RSC Adv., 2015, 5, 106519-106522.

11 W. Ren, Z. Zheng, C. Xu, C. Niu, Q. Wei, Q. An, K. Zhao, M. Yan, M. Qin and L. Mai, Nano Energy, 2016, 25, 145-153.

12 H. Li, L. Peng, Y. Zhu, D. Chen, X. Zhang and G. Yu, Energy Environ. Sci., 2016, 9, 3399-3405.

13 L. Liang, Y. Xu, Y. Li, H. Dong, M. Zhou, H. Zhao, U. Kaiser and Y. Lei, J. Mater. Chem. A, 2017, 5, 1749-1755.
14 L. Zhang, S. X. Dou, H. K. Liu, Y. Huang and X. Hu, Adv. Sci., 2016, 3, 1600115.

15 Y. Wang, R. Xiao, Y.-S. Hu, M. Avdeev and L. Chen, Nat. Commun., 2015, 6, 6954.

16 S. Guo, H. Yu, P. Liu, Y. Ren, T. Zhang, M. Chen, M. Ishida and H. Zhou, Energy Environ. Sci., 2015, 8, 1237-1244.

17 L. S. Plashnitsa, E. Kobayashi, Y. Noguchi, S. Okada and J. Yamaki, J. Electrochem. Soc., 2010, 157, A536-A543.

18 D. Kundu, R. Tripathi, G. Popov, W. R. M. Makahnouk and L. F. Nazar, Chem. Mater., 2015, 27, 885-891.

19 P. Barpanda, G. Liu, C. D. Ling, M. Tamaru, M. Avdeev, S.-C. Chung, Y. Yamada and A. Yamada, Chem. Mater., 2013, 25, 3480-3487.

20 Z. Lu and J. R. Dahn, Chem. Mater., 2001, 13, 1252-1257.

21 D. Buchholz, L. G. Chagas, C. Vaalma, L. Wu and S. Passerini, J. Mater. Chem. A, 2014, 2, 13415-13421.

22 J. Liu, J. G. Zhang, Z. G. Yang, J. P. Lemmon, C. Imhoff, G. L. Graff, L. Y. Li, J. Z. Hu, C. M. Wang, J. Xiao, G. Xia, V. V. Viswanathan, S. Baskaran, V. Sprenkle, X. Li, Y. Shao and B. Schwenzer, Adv. Funct. Mater., 2013, 23, 929-946.

23 A. Eftekhari, Z. Jian and X. Ji, ACS Appl. Mater. Interfaces, 2017, 9, 4404-4419.

24 W. Song, X. Cao, Z. Wu, J. Chen, K. Huangfu, X. Wang, Y. Huang and X. Ji, Phys. Chem. Chem. Phys., 2014, 16, 17681-17687.

25 H. Gao and J. B. Goodenough, Angew. Chem., Int. Ed., 2016, $55,1-6$.

26 W. Zhou, L. Xue, X. Lu, H. Gao, Y. Li, S. Xin, G. Fu, Z. Cui, Y. Zhu and J. B. Goodenough, Nano Lett., 2016, 16, 78367841.

27 H. Gao, Y. Li, K. Park and J. B. Goodenough, Chem. Mater., 2016, 28, 6553-6559.

28 S. Y. Lim, H. Kim, R. A. Shakoor, Y. Jung and J. W. Choi, J. Electrochem. Soc., 2012, 159, A1393-A1397.

29 P. Barpanda, T. Ye, M. Avdeev, S. C. Chung and A. Yamada, J. Mater. Chem. A, 2013, 1, 4194-4197.

30 A. Ponrouch, E. Marchante, M. Courty, J. M. Tarascon and M. R. Palacin, Energy Environ. Sci., 2012, 5, 8572-8583.

31 D. Wang, Q. Liu, C. Chen, M. Li, X. Meng, X. Bie, Y. Wei, Y. Huang, F. Du, C. Wang and G. Chen, ACS Appl. Mater. Interfaces, 2016, 8, 2238-2246.

32 Y. Niu, M. Xu, C. Guo and C. M. Li, J. Colloid Interface Sci., 2016, 474, 88-92.

33 Q. Ni, Y. Bai, F. Wu and C. Wu, Adv. Sci., 2017, 4, 1600275. 